\title{
Journal of Supply Chain Management
}

\section{Building Bridges: Towards Alternative Theory of Sustainable Supply Chain Management}

Lee Matthews, Damien Power, Anne Touboulic and Leonardo Marques

Article information:

Lee Matthews, Damien Power, Anne Touboulic and Leonardo Marques (2016), "Building Bridges: Towards Alternative Theory of Sustainable Supply Chain Management," Journal of Supply Chain Management, Vol. 52 No. 1.

\begin{abstract}
We contend that the development of sustainable supply chain management (SSCM) theory has been impaired by a lack of paradigmatic diversity in the field. The contested nature of the concept of sustainability has been repressed in SSCM theory, which has led to SSCM cutting itself off from debates that could be the source of inspiration for the development of interesting theory. We adopt the problematization approach proposed by Alvesson and Sandberg (2011) in order to unveil some of SSCM's unquestioned assumptions, propose an alternative assumption ground and in this way move towards stronger theory in SSCM. We use paradoxical framing to make sense of the inherent tensions between the different levels of sustainability, and between the different types of theory being produced in response to the challenges of sustainability. We articulate a number of foundational assumptions for an alternative theory of SSCM that emerge from the various tensions identified between the different paradigms of sustainability. Finally, we identify a number of ideas for future research that would enable researchers to empirically explore the alternative assumptions.
\end{abstract}

Keywords: paradox; paradigms; problematization; sustainable supply chain management 


\section{INTRODUCTION}

In the last quarter of the twentieth century, the ecological footprint of the politicaleconomic system overshot the limits of the natural system upon which it ultimately depends (WWF, 2014). Of the nine planetary boundaries that humanity cannot safely transgress, empirical evidence suggests that three have already been breached, those related to climate change, the nitrogen cycle and biodiversity loss (Rockström et al., 2009). The consequences for humanity are likely to be profound in the current century, with ecological degradation likely to cancel out the gains being made in social development (UNDP, 2013). Global supply chains play a significant part in this degradation, as they are one of the principal means through which manufactured capital displaces natural capital. Paradoxically, however, supply chain management (SCM) also has the potential to be a "locus for much of the change towards sustainability and make important contributions to the sustainability of the broader ecosystems" (Mohrman \& Worley, 2010, p. 291).

Theory can play an important role in realizing this potential but it needs to first be recognized that sustainability is fundamentally different from every other problem within SCM. Sustainability is first and foremost a moral question as it concerns the legacy that is left to future generations (Ekins, 2000; Shrivastava, 1995; Speth, 2008). To date, it has rarely been treated as such within SCM. Instead, SSCM has tended to rely on a win-win framing that emphasizes the potential contribution of sustainability towards the financial bottom line (Golicic \& Smith, 2013).

The introduction of the triple bottom line (TBL) into SCM marked a paradigm shift within the field and facilitated the organization of Sustainable SCM (SSCM) into a meaningful research program. To date however, SSCM theory has not been able to explain how the pursuit of win-win opportunities can meaningfully contribute towards returning the political- 
economic system from a state of ecological overshoot. This represents a significant anomaly and suggests that a new paradigm shift may be required.

The objective of the paper is to explore what the next paradigm shift in SSCM might look like. To do so, the following research questions were answered: RQ1. How can alternative theories of SSCM be developed? RQ2. What assumptions need to be challenged in order for alternative theories of SSCM to emerge? RQ3. What assumptions are needed to develop alternative theories of SSCM? This paper seeks to answer these questions by eschewing the gap-spotting approach of gradualist research in favor of a problematization approach, which constructs extant knowledge as problematic rather than as factual, and involves questioning the dominant assumptions underlying a field in order to develop new theoretical approaches (Alvesson \& Sandberg, 2011).

The paper is logically structured around answers to our research questions. First, we clarify what we mean by theory and present problematization as the adopted method of theory development. Second, we identify and evaluate the dominant assumptions within SSCM theory. Third, we present an alternative theory of SSCM. We articulate a number of foundational assumptions in this section. Finally, conclusions are drawn.

RQ1: How can alternative theories of SSCM be developed?

There is much discussion among management scholars about the nature and definition of theory and what the activity of theory development should entail (Alvesson \& Sandberg, 2011; Colquitt \& Zapata-Phelan, 2007; Sutton \& Staw, 1995). Weick (1995) makes clear distinctions between theory, as an end, and theorizing, as a means. Given the complexity of the problem of environmental sustainability, we believe that the development of a theory of SSCM will necessarily require a lengthy process of theorizing.

This process of theorizing will require an alternative to positivistic approaches to theory development that seek conceptual closure. Instead, a process perspective on theory 
development is required that constructs theorizing as a dynamic play with knowledge. This process will necessarily produce less "full-fledged theories" than in other areas of SCM and more "interim struggles" (Weick, 1995, p. 389). These struggles will take the form of theorists trying to free themselves from dominant modes of thinking.

Theory development is paradigmatic in nature (Burrell \& Morgan, 1979). The current assumptions within a given paradigm will restrict how theorists think about a given problem. As a result, theorists will struggle to free themselves from such assumptions. Bacharach

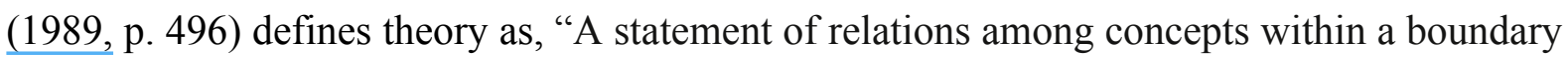
set of assumptions and constraints. It is no more than a linguistic device used to organize a complex empirical world." This definition clearly emphasizes that assumptions are central to theory development and that consequently any theory will be bounded by the researcher's assumptions about the topic. Fundamental to this process is for any "relations among concepts" to be bounded by the ontological and epistemological stance taken by those developing theory. All theory is an outcome of assumptions about what reality is and whether/how it can be known.

In line with Bartunek et al. (2006) and Davis (1971), we contend that not all theoretical efforts can be viewed as interesting. Interesting research and theories appear to be those that are counterintuitive and challenge established knowledge (Bartunek et al., 2006). Davis (1971, p. 311) argues that interesting theory stands out in contrast to "routinely taken-forgranted propositions". Consequently, it is necessary to challenge existing assumptions in order for interesting theory to emerge (Bartunek et al., 2006; Davis, 1971; Weick, 1989).

The dominant assumption within SSCM appears to be that economic, environmental and social sustainability can be achieved simultaneously. Such an approach tends to legitimize practices that "make business sense" and considers more radical, non-economically focused approaches as unsustainable (Pagell, M. \& Shevchenko, 2014). This win-win approach to 
SSCM stands in contrast to other literatures on sustainability. For example, it has long been recognized within the economics literature that sustainability will require painful trade-offs (Barbier, 1987; Ekins, 2000; Lecomber, 1975), and tradeoffs are emerging as a theme within the management literature on sustainability (Hahn et al., 2010; Hahn, Pinkse, et al., 2014; Hahn, Preuss, et al., 2014).

The discrepancy between SSCM theory to date and these other literatures suggests the possibility that we have either taken the wrong approach to the problem or defined it too narrowly. As a result, what is now needed is to engage in a dialectical interrogation of the familiar (Alvesson \& Sandberg, 2011; Astley \& Van de Ven, 1983; Wickert \& Schaefer, 2015), which will require theorists to "adopt a counter-stance to their preferred understanding of the world' (Alvesson \& Sandberg, 2013).

A systematic approach to developing such a 'counter-stance' is required. There is an incipient literature on this approach, exemplified by the work by Alvesson and Sandberg (2011). Problematization (Alvesson \& Sandberg, 2011) is offered as the means through which SSCM can develop interesting, relevant and useful theories. To develop an alternative assumption ground, the specific problematization method of counterinduction is used (Alvesson \& Sandberg, 2011; Feyerabend, 2010). Counterinduction assumes that it is not possible to produce an alternate assumption ground "from the inside" of our own theories, and that instead theorists need to somehow find an "external standard of criticism" (Feyerabend, 2010, p. 15). In the case of SSCM, this "external standard" comes from theories being developed within sustainability paradigms that are different from our own.

\section{PROBLEMATIZATION OF CURRENT SSCM ASSUMPTIONS}

The first step in our problematization approach consists of identifying, articulating and evaluating the dominant assumptions of SSCM research. To do this, we must look outside of our own theory to find an external standard of critique. In order to do this, we first need to 
identify and map the paradigms that structure theory development on sustainability. Although theorists in these paradigms are working on problems quite different from those we are concerned with within SSCM, their work can be useful in shedding light on the limitations of the boundary assumptions of our theories.

\section{Paradigms of Sustainability Analytical Framework}

The original framework for reflecting upon assumptions within the field of management is the Burrell and Morgan (1979) sociological framework on organizational paradigms, which can be seen in Figure 1 below. This framework was rejected as a tool for mapping sustainability theories as it was believed to better reflect the dominant concerns of the fields of sociology and organizational studies in the late seventies than the concerns of sustainability theorists at the start of twenty first century.

-Insert Figure 1 Approximately Here-

The need for a new framework can be shown with an example. As can be seen in Figure 1, the phenomenology of Heidegger and the critical theory of the Frankfurt School are placed in different paradigms within the Burrell and Morgan (1979) framework due to their differences concerning the need for radical social change. However, for sustainability theorists their shared emphasis on humanity's exploitation of nature is a more important consideration. This leads us to believe that they belong in the same paradigm - a sustainability paradigm.

As a result, we present an alternative framework for mapping sustainability paradigms (Figure 2). Using Burrell and Morgan (1979) framework as an inspiration, the alternative framework shown in Figure 2 allows us to map and reflect upon the theories of sustainability within, and relevant to, the management field. This framework consists of two dimensions sustainability and change. 
Sustainability is an essentially contested concept (Ehrenfeld, 2008). One of the defining features of such a concept is that there is typically greater consensus concerning the nature of the problem than the solution to the problem (Gallie, 1956). In the case of sustainability, this means that there will tend to be much higher levels of agreement on defining the problem of unsustainability than how to transition towards sustainable development. While many SSCM researchers can agree that we have exceeded the ecological capacity of our planet and are faced with tremendous social challenges as a result, there is considerably less agreement about how these problems should be addressed. Often these differences are not explicitly acknowledged within the SSCM literature. There are two established perspectives on how to achieve sustainability (Speth, 2008): the conflicting perspectives of strong sustainability (SS) e.g. Daly (1996) and weak sustainability (WS) e.g. Solow (1974) and Hartwick (1977). These two perspectives anchor the endpoints of the sustainability dimension.

Both WS and SS define sustainability as the ability to maintain at least a non-declining stock of capital for future generations (Ekins, 2000; Neumayer, 2003). Unlike the paradigm of neoclassical economics they challenged, both WS and SS include natural capital within their definition of capital stock. As a result, natural capital will inevitably act as a limit upon the scale and scope of economic activity.

The differentiating factor between WS and SS concerns the extent to which economic activity is limited by natural capital. For WS, growth in manufactured capital is allowed if its value is greater than the value of any natural capital consumed in the process (Solow, 1974). At the very weak end of the sustainability dimension all natural capital can be replaced by manufactured capital subject to the constraint that the resulting stock of capital has a greater value as a result (Hartwick, 1977). Most theorists however will reject this view and believe that some forms of natural capital are too critical to be substituted by manufactured capital e.g. climate stabilization (Ekins, 2000). To a greater extent than WS, SS views natural capital 
and manufactured capital as complements, meaning that beyond a certain scale of economic activity, it is unsustainable to destroy natural capital to create manufactured capital (Daly, 1996).

For WS, sustainability is achieved through ensuring the optimal balance between the production of manufactured capital and the consumption of natural capital, while for SS it is achieved through reforming the political-economic system so that it is able to operate at a sustainable scale (Ekins, 2000; Neumayer, 2003). As we move along the sustainability dimension from weak to strong sustainability, natural capital becomes more of a limiting factor for economic activity, including SCM.

\section{Change Dimension}

As sustainability requires fundamental change in how the economic system and its institutions are organized, the philosophical dimension of the Burrell and Morgan (1979) framework has been replaced with a dimension that is concerned with the process of change. This dimension is introduced as a means to examine the emphasis placed on change within theories of sustainability, specifically the assumptions about the extent to which change is possible and how it is to be achieved.

This dimension concerns the relationship between structure and action that is central to the process of change (Giddens, 1979). There is a dialectical relationship between the two aspects of change as they are mutually constitutive. However, different theories will tend to give greater emphasis to one of the two aspects of change. Humanist theories (left side of the dimension) tend to emphasize the ontological priority of action over structures and believe that agents have a high degree of autonomy. While more structuralist theories (right side of the dimension) either tend to believe that agents have little autonomy or give little weight to the question of agency. The theorist's position on this question will determine the possibilities for change that are captured in their theory. 


\section{SSCM AND THE FOUR PARADIGMS OF SUSTAINABILITY}

The combination of the two dimensions yields four sustainability paradigms. A paradigm defines what problems are legitimate for a community of researchers and theorists to work on. It determines what questions can be meaningfully asked, how they can be purposefully answered, and how those answers should be evaluated (Kuhn, 2012).

Each of the sustainability paradigms is based on different assumptions about sustainability and change. As a result, they are concerned with different problems, which is the cause of the conceptual tensions that exist between the different paradigms. Despite this, they have much in common that differentiates them from traditional management paradigms. All four paradigms are normative, believing that natural capital should be valued, although to differing degrees. They all advocate changes in how the political economy is organized, although they place a different emphasis on the possibility, desirability and means for change.

Each of the four paradigms offer potential opportunities for theorists to problematize the restrictive assumptions upon which SSCM has thus far been constructed and create an alternative assumption ground for the development of an alternative theory of SSCM. The discussion of paradigms that follows situates SSCM in relation to the four paradigms. The paradigms are used as an external standard of criticism to problematize the assumptions of SSCM theory.

RQ2: What current assumptions need to be challenged in order for alternative theories of SSCM to emerge?

To position SSCM in relation to the four paradigms, we have reviewed SSCM papers published between 1993 and 2013. A systematic search of three databases (Proquest, Business Source Premier, and Science Direct) produced a sample of 181 empirical papers. A single search string was used in all databases: "supply chain" OR "supply network" OR “supply management" OR purchasing OR sourcing OR procurement) AND (sustainab* OR green OR environment*). 
Consistent with the authors' belief that environmental sustainability is the foundation for economic and social sustainability (Czech, 2013; Daly, 1996; Dietz \& O'Neill, 2013; Ehrenfeld, 2008; Ekins, 2000; Griggs et al., 2013; Huesemann \& Huesemann, 2011; Jackson, 2009; Speth, 2008), the focus of the review was to determine the contribution that SSCM can make towards environmental sustainability. Only 15 empirical studies were found to have environmental performance as their focus (i.e. as a dependent variable). Another group of 17 studies has used environmental practices as the dependent variable, but do not address the environmental outcome of such practices. By practices, we refer to terms such as environmental purchasing, green purchasing, and green supply chain management. Environmental performance here is defined as reductions in the environmental impact of the supply chain. In contrast, a recent meta-analysis from Golicic and Smith (2013), covering a similar time period and scope found 31 studies where financial performance was the dependent variable. We believe both results illustrate the trend in our field to skew the assessment of SSCM success towards financial rather than environmental outcomes. As will be shown, this positions SSCM in a problematic relationship to all four sustainability paradigms.

Table 1 represents the analysis of those articles with environmental performance as their focus. The table maps the measures used in these studies to each of the nine Planet Boundaries (Rockström et al., 2009). Next, the table will be interpreted through the prism provided by the sustainability paradigms framework. This process of interpretation involves imagining how SSCM would look to theorists working in each of these paradigms. We start with the Utilitarian paradigm, as this is where we have provisionally positioned SSCM.

\section{Utilitarian Paradigm}


This is a WS paradigm that has a structuralist position on change. A typical problem within this paradigm is how to decouple manufactured and natural capital through radical increases in resource productivity (Elkington, 1998). A common goal for such productivity increases is 'Factor 10', which aims to reduce resource use by $90 \%$ (DeSimone \& Popoff, 1997; Elkington, 1998). From a utilitarian perspective, perhaps the most serious problem with SSCM is that it is not currently able to show how SCM is able to deliver such radical reductions in environmental impact.

Table 1 above shows the limited understanding that SSCM theory has of the environmental effectiveness of SSCM strategies. The studies often adopt measurement procedures based on firm-level subjective data, collected through single respondent surveys. This picture raises three major concerns. First, there is no discussion of the interaction between firm-level performance and environmental levels of analysis i.e. it is not clear if the actions taken by the firm are commensurate with what is required to achieve environmental sustainability. Second, measurement is restricted to subjective data, collected via surveys. Measures are limited to perception-based answers of single respondents for each firm at the same point in time, which is subject to high levels of social desirability bias. Third, respondents' perceptions are captured through ordinal scales and do not provide percentage or absolute values regarding the reductions in environmental damage that have been achieved. Such measures offer little insight, if any, into how exactly SCM is contributing towards decoupling manufactured and natural capital. It is for this reason that SSCM is provisionally placed in the Utilitarian paradigm, but at the very weak end of the sustainability dimension.

\section{Systemic paradigm}

This is an SS paradigm that has a structuralist perspective on change. Theories in this paradigm view the unsustainable society as being inherently unstable. Such a society is 
necessarily defined by the fundamental contradiction inherent in the relationship between the exponential growth of the economic sub-system and the non-growing nature of the natural system (Daly, 1996; Ekins, 2000). From an SS perspective, this contradiction can only be resolved through a radical reduction in the scale of the former. This will either take the form of the collapse of the sub-system or a profound change in how it is organized (Daly, 1996; Ekins, 2000). Both resolutions will have enormous implications for the design and management of supply chains.

Theorists in the systemic paradigm adopt a system level view of sustainability. A typical problem for this paradigm is to determine the optimum scale of economic activity in terms of energy and material throughput. For a systemic theory of SSCM, the twin challenges would be how to deliver the radical reductions in throughput needed to operate within this scale and how to keep throughput levels at this level indefinitely.

From the systemic perspective, the inability of SSCM theory to capture the relationship between SCM and the protection of natural capital is more serious than from the utilitarian perspective. Perhaps the most serious issue is that SSCM ignores the question of scale. As we can see from Table 1, SSCM is not able to make the all-important distinction between relative and absolute reductions in environmental impact. This distinction is of the highest importance for understanding the extent to which the scale of economic activity is sustainable. Relative reductions in impact are meaningless from an ecological perspective. It is absolute impact that matters (Jackson, 2009).

The inability of SSCM to explain how supply chain strategies are able to deliver the kinds of reduction in throughput that are consistent with what is ecologically required, or even to recognize this as a legitimate problem for theory to address, is a major problem from the systemic perspective.

\section{Constructionist Paradigm}


This is a WS paradigm that has an agency perspective on change. Theories in this paradigm are concerned with how supply chain stakeholders make sense of sustainability. A typical problem here might be how practitioners working towards sustainability will need to cope with multiple and conflicting goals, internal conflicts, and the cognitive and emotional distress that this may cause (Hahn, Preuss, et al., 2014). What discourses do practitioners draw upon to decide what natural capital should be considered critical? Does the narrow selection of planetary boundaries covered in Table 1 above represent their answer to this question or those of the researchers designing the surveys? If it does represent the practitioners' answer to the question, why do they place such a low value on some of the planetary boundaries?

From this perspective, the picture of sustainability produced by SSCM to date seems insufficiently rich. Little is known about what affected stakeholders actually think, how they react, and what they feel. SSCM seems insufficiently sensitive to issues such as emotion (Touboulic et al., 2014) and the processes of sensemaking (van der Heijden et al., 2010). Encouragingly, there are signs within SSCM of a growing recognition that sustainability is an ambiguous concept, composed of conflicting pressures, which are harder to reconcile than had previously been acknowledged (Gold et al., 2013; Reuter et al., 2012; Wang \& Sarkis, 2013; Wu et al., 2014).

\section{Critical Paradigm}

Theorists working in the critical paradigm tend to focus on many of the same structural contradictions as those theorists working in the systemic paradigm, but are more concerned with how consciousness shapes, and is shaped by, those contradictions. Like theories in the constructionist paradigm, critical theories view systems as emergent, but unlike constructionist theories, they stress the need for more radical forms of change. 
Theory in this paradigm is highly normative and is trying to get ahead of practice. The early sustainability literature represents the heyday for this paradigm. This literature was explicitly critical and normative, offering critiques of existing economic and managerial paradigms (Gladwin et al., 1995) and developing ideal types for practitioners to work towards, such as the ecologically sustainable organization (Starik \& Rands, 1995), and the ecocentric manager (Shrivastava, 1995). There have been recent calls for theories of corporate sustainability to return to their normative origins once again (Banerjee, 2012; Gladwin, 2012).

From a critical perspective, there appears to be a common confusion between means and ends within SSCM theory. For economic and social sustainability to occur, the end is for the economic system and its institutions to operate within the carrying capacity of the natural system (Griggs et al., 2013). Within SSCM however, environmental action is often not an end in itself but is constructed as a means to improving financial performance (Golicic \& Smith, 2013). When it is considered as an end, as in the research presented in Table 1, the environmental actions are uncritically accepted as being sufficient to the scale of the problem. This means that SSCM theory is potentially serving a legitimizing effect for actions that are environmentally ineffective. While such theory purports to be objective, it leaves itself open to the criticism that it is unwittingly serving an ideological purpose (Banerjee, 2012), i.e. the continuation of business as (almost) usual (Ehrenfeld, 2008).

Unless theory is able to connect the means to the end of ecological sustainability it is of limited, and possibly even questionable, value. Encouragingly, there are signs within SSCM of an incipient problematization of the win-win focus of the TBL discourse. There is increased recognition that SSCM strategies will not always provide payback in economic terms (Awaysheh \& Klassen, 2010; Wang \& Sarkis, 2013).

\section{TOWARDS AN ALTERNATIVE THEORY OF SSCM: A PARADOXICAL APPROACH}


RQ3: What assumptions are needed to develop alternative theories of SSCM?

Having problematized the assumptions of SSCM theory, we now build on these reflections to create an alternative assumption ground for SSCM that can serve as the basis for future theory development.

Consistent with the problematization approach taken, this alternative assumption ground can be used in the following three ways to further develop theory. First, it can be used as an external standard against which $\mathrm{SSCM}$ as currently constituted can clarify its own assumption ground and in so doing sharpen its own arguments. Second, it can be embraced as an alternative approach to SSCM. And third, elements of both approaches can be synthesized to develop a new theory of SSCM.

To begin the process of developing alternative theories of SSCM, we introduce three foundational assumptions about the nature of a theory of sustainability. It is our belief that because sustainability is so profoundly different to other problems within SCM, we need a new type of theory.

As sustainability is an essentially contested concept, theories are being developed in different paradigms as theorists work on very different sustainability problems. All of these theories are relevant to SSCM but are difficult to integrate into a single theory of sustainability due to the high level of incommensurability of the assumptions underpinning the different paradigms. These assumptions concern the level at which sustainability is a meaningful concept, the degree of change required to effect a transition to an ecologically sustainable political-economic system, and the role that theory plays in this transition.

One approach to the pluralism inherent to the field of sustainability is to bracket it and work on simple problems that are consistent with the broader subject domain, such as whether it "pays to be green". This is largely what SSCM has done to date. The other is to embrace pluralism and use it as the basis for theory development - the approach proposed 
here. Pluralism can be embraced through the adoption of paradox as a meta-theoretical lens. Paradoxes at the meta-theoretical level are defined as those "interesting tensions, oppositions, and contradictions between theories which create conceptual difficulties" (Poole \& Van de Ven, 1989, p. 562). This leads to our first foundational assumption (FA):

FA1: Given that sustainability is an essentially contested concept, a theory of SSCM will benefit from the adoption of paradox as its meta-theoretical lens.

Two paradoxes that have the potential to be fruitful for theory development within SSCM have been identified. The first paradox concerns the tensions between the different levels of analysis of the various sustainability theories. The second concerns the difficulties of working with theories of sustainability that serve different purposes, such as explanation, critique, and normativity. By embracing these tensions and difficulties, a paradox lens can lead to the development of theory that is both multilevel in its scope and able to serve multiple purposes.

By definition a theory of SSCM should be multilevel, encompassing individuals, the organization, inter-organizational networks, and macro-environmental levels (Starik \& Rands, 1995). Such an approach will undoubtedly provide a richer and more synergistic picture for theorists to work with. Recent literature reviews of SSCM research have suggested the need to adopt a network-level perspective to address sustainability challenges (Miemczyk et al., 2012).

Developing a multi-level theory of sustainability represents considerable difficulty as the different levels of sustainability tend to be theorized within different paradigms. For example, inter-organizational networks may best be theorized from a structuralist perspective, whereas theories attempting to make sense of individual behavior will likely place a greater emphasis on agency rather than structure. A paradoxical theory would embrace this complexity rather than avoid it in the belief that it can be the source of interesting theory (Hitt et al., 2007). Thus:

FA2: A paradoxical theory of SSCM will use the tensions between levels of analysis to stimulate theory development. 
Another tension that must be managed is the need for a theory of sustainability to go beyond explanation. Because theory plays a part in the social construction of sustainability, it will need to be normative as well as explanatory (Banerjee, 2012; Gladwin, 2012). It is difficult for theory to serve both purposes as each type of theory is developed differently and is evaluated according to different criteria (Alvesson \& Skoldberg, 2009). Explanatory theories tend to be less normative, as they are concerned with explaining what is the case. Because such theories eschew the adoption of a critical stance, they can potentially lead to the legitimation of what is observed (Alvesson \& Willmot, 2012). In contrast, normative theories often fail to meet the criteria of a good explanatory theory, as they are concerned with what should be the case. This can lead to the development of theories that are perceived to be idealistic and can potentially be dismissed as being impractical (Alvesson \& Skoldberg, 2009; Spicer et al., 2009). The adoption of a paradox lens can potentially help a theory to steer a middle path between the Scylla of legitimation and the Charybdis of utopianism.

FA3: A paradoxical theory of SSCM will need to strike a balance between the contradictory purposes of explanation and normativity.

\section{CONCLUSION AND FUTURE RESEARCH}

Gladwin et al. (1995, p. 881) noted that "little theoretical progress can be made regarding sustainable enterprise on unquestioned grounds." In this paper we have fully embraced this perspective and offered a constructive critique of current SSCM assumptions in order to progress towards the development of alternative theories of SSCM.

It is important to note here that we recognize and are mindful of the political aspects involved in adopting a problematization approach, as it challenges assumptions that may be held strongly by the community (Alvesson \& Sandberg, 2011). We recognize that the field is not homogenous and that there is a diversity of approaches to SSCM problems. We also realize that some researchers and managers are already questioning some of the field's 
commonly accepted assumptions. However in our view, there does exist a dominant and recognizable core of mainstream SSCM research grounded in what we have labeled the Utilitarian paradigm of sustainability. This results in the field being pulled towards accepted norms and discourses at the expense of paradigm plurality. Such pluralism is vitally important for the field of management studies (Van Maanen, 1995), in particular in relation to contested concepts. We echo the calls for diversity that have previously been made by researchers in SCM (Boyer \& Swink, 2008; Burgess et al., 2006). We believe such diversity will help prevent SSCM from becoming one dimensional and irrelevant, and will help stimulate the creative approaches needed to uncover all the mysteries that are central to the development of new knowledge (Alvesson \& Kärreman, 2007).

\section{Implications for Future Research}

In the paper, we argue that there is a need for a paradigm shift within SSCM so that we can theorize about how SSCM can contribute towards the transition to sustainability through the protection of natural capital. Three research opportunities suggest themselves. First, natural sciences can provide objective ecological metrics to assess the environmental effectiveness of current SSCM initiatives. Results from such research can provide a new baseline for corporate sustainability impact and inform both public policy and corporate strategy. Second, strong sustainability perspectives, such as ecological economics (Daly, 1996), offer the theoretical grounds for examining how political economic structures (such as 'free trade') and discourses (such as globalization) limit the effectiveness of sustainability initiatives. Such research should include a comprehensive analysis of the context and institutional forces shaping the corporate agenda for sustainability. Third, through adopting a

strong sustainability lens researchers can explore how firms move from limited, harm reduction initiatives to having positive ecological impacts. Furthermore, this research stream 
can investigate how the stake of Nature is represented (or not) in current management praxis and strategic planning.

In conclusion, it is not our intention to engage in a judgmental, unconstructive and utopian critique of current SSCM research but rather we are seeking to provide a space for interesting theory to emerge in future research through a problematization approach (Alvesson \& Sandberg, 2011; Astley \& Van de Ven, 1983; Wickert \& Schaefer, 2015). 


\section{REFERENCES}

Alvesson, M., \& Kärreman, D. A. N. (2007). Constructing mystery: empirical matters in theory development. Academy of Management Review, 32(4), 1265-1281.

Alvesson, M., \& Sandberg, J. (2011). Generating research questions through problematization. Academy of Management Review, 36(2), 247-271.

Alvesson, M., \& Sandberg, J. (2013). Constructing Research Questions: Doing Interesting Research. London: Sage.

Alvesson, M., \& Skoldberg, K. (2009). Reflexive Methodology: New Vistas for Qualitative Research (2nd ed.). London: Sage.

Alvesson, M., \& Willmot, H. (2012). Making Sense of Management (2nd ed.). London: Sage.

Astley, W. G., \& Van de Ven, A. H. (1983). Central perspectives and debates in organization theory. Administrative Science Quarterly, 28(2), 245-273.

Awaysheh, A., \& Klassen, R. D. (2010). The impact of supply chain structure on the use of supplier socially responsible practices. International Journal of Operations \& Production Management, 30(12), 1246-1268.

Bacharach, S. B. (1989). Organizational theories: some criteria for evaluation. Academy of Management Review, 14(4), 496-515.

Banerjee, S. B. (2012). Critical perspectives on business and the natural environment In P. Bansal \& A. J. Hoffman (Eds.), The Oxford Handbook of Business and the Natural Environment. Oxford: Oxford University Press.

Barbier, E. B. (1987). The concept of sustainable development. Environmental Conservation, 14(2), 101-110.

Bartunek, J. M., Rynes, S. L., \& Ireland, R. D. (2006). What makes management research interesting, and why does it matter? Academy of Management Journal, 49(1), 9-15.

Boyer, K. K., \& Swink, M. L. (2008). Empirical Elephants--Why Multiple Methods are Essential to Quality Research in Operations and Supply Chain Management. Journal of Operations Management, 26(3), 338-344.

Burgess, K., Singh, P. J., \& Koroglu, R. (2006). Supply chain management: a structured literature review and implications for future research. International Journal of Operations \& Production Management, 26(7), 703-729.

Burrell, G., \& Morgan, G. (1979). Sociological Paradigms and Organizational Analysis. London: Heinemann.

Chiou, T.-Y., Chan, H. K., Lettice, F., \& Chung, S. H. (2011). The influence of greening the suppliers and green innovation on environmental performance and competitive advantage in Taiwan. Transportation Research Part E: Logistics and Transportation Review, 47(6), 822-836.

Colquitt, J. A., \& Zapata-Phelan, C. P. (2007). Trends in theory building and theory testing: a fivedecade study of the the Academy of Management Journal. Academy of Management Journal, 50(6), 1281-1303.

Czech, B. (2013). Supply Shock: Economic Growth at the Crossroads and the Steady State Solution. Gabriola Island: New Society Publishers.

Daly, H. E. (1996). Beyond Growth: The Economics of Sustainable Development. Boston: Beacon Press.

Davis, M. S. (1971). That's Interesting. Philosophy of Social Sciences, 1(4), 309-343.

DeSimone, L. D., \& Popoff, F. (1997). Eco-efficiency: The Business Link to Sustainable Development. Cambridge: The MIT Press.

Dietz, R., \& O'Neill, D. (2013). Enough is Enough: Building a Sustainable Economy in a World of Finite Resources. Abingdon: Routledge.

Ehrenfeld, J. R. (2008). Sustainability by Design. New Haven: Yale University Press.

Ekins, P. (2000). Economic Growth and Environmental Sustainability. London: Routledge.

Elkington, J. (1998). Cannibals with Forks. London: New Society.

Feyerabend, P. K. (2010). Against Method (4th ed.). London: Verso. 
Gallie, W. B. (1956). Essentially contested concepts. Proceedings of the Aristotelian Society, 56, 167198.

Giddens, A. (1979). Central Problems in Social Theory. Berkeley: University of California Press.

Gimenez, C., \& Sierra, V. (2013). Sustainable Supply Chains: Governance Mechanisms to Greening Suppliers. Journal of Business Ethics, 116(1), 189-203.

Gladwin, T. N. (2012). Capitalism critique: systemic limits on business harmony with nature. In P. Bansal \& A. J. Hoffman (Eds.), The Oxford Handbook on Business and the Natural Environment Oxford: Oxford University Press.

Gladwin, T. N., Kennelly, J. J., \& Krause, T. (1995). Shifting paradigms for sustainable development: implications for management theory and research. Academy of Management Review, 20(4), 874-907.

Gold, S., Hahn, R., \& Seuring, S. (2013). Sustainable supply chain management in "Base of the Pyramid" food projects-A path to triple bottom line approaches for multinationals? International Business Review, 22(5), 784-799.

Golicic, S. L., \& Smith, C. D. (2013). A meta-analysis of environmentally sustainable supply chain management practices and firm performance. Journal of Supply Chain Management, 49(2), 78-95.

González, P., Sarkis, J., \& Adenso-Díaz, B. (2008). Environmental management system certification and its influence on corporate practices. International Journal of Operations \& Production Management, 28(11), 1021-1041.

Green Jr., K. W., Zelbst, P. J., Bhadauria, V. S., \& Meacham, J. (2012). Do environmental collaboration and monitoring enhance organizational performance? Industrial Management + Data Systems, 112(2), 186-205.

Green Jr., K. W., Zelbst, P. J., Meacham, J., \& Bhadauria, V. S. (2012). Green supply chain management practices: impact on performance. Supply Chain Management: An International Journal, 17(3), 290-305.

Griggs, D., Stafford-Smith, M., Gaffney, O., Rockström, J., Öhman, M. C., Shyamsundar, P., . . . Noble, I. (2013). Sustainable development goals for people and planet. Nature, 495, 305-307.

Hahn, T., Figge, F., Pinkse, J., \& Preuss, L. (2010). Trade-offs in corporate sustainability: you can't have your cake and eat it. Business Strategy and the Environment, 19(4), 217-229.

Hahn, T., Pinkse, J., Preuss, L., \& Figge, F. (2014). Tensions in corporate sustainability: towards an integrative framework. Journal of Business Ethics, 127(2), 297-316.

Hahn, T., Preuss, L., Pinkse, J., \& Figge, F. (2014). Cognitive frames in corporate sustainability: managerial sensemaking with paradoxical and business case frames. Academy of Management Review, 39(4), 463-487.

Hartwick, J. M. (1977). Intergenerational equity and the investing of rents from exhaustible resources. The American Economic Review, 67(5), 972-974.

Hitt, M. A., Beamish, P. W., Jackson, S. E., \& Mathieu, J. E. (2007). Building theoretical and empirical bridges across levels: Multilevel research in management. Academy of Management Journal, 50(6), 1385-1399.

Hong, P., Kwon, H.-B., \& Roh, J. J. (2009). Implementation of strategic green orientation in supply chain. European Journal of Innovation Management, 12(4), 512-532.

Huesemann, M., \& Huesemann, J. (2011). Techno-fix: Why Technology Won't Save Us or the Environment Gabriola Island: New Society Publishers.

Jackson, T. (2009). Prosperity Without Growth: The Transition to a Sustainable Economy. London: Earthscan.

Kuhn, T. S. (2012). The Structure of Scientific Revolutions. Chicago: The University of Chicago Press.

Laosirihongthong, T., Adebanjo, D., \& Tan, K. C. (2013). Green supply chain management practices and performance. Industrial Management + Data Systems, 113(8), 1088-1109.

Large, R. O., \& Thomsen, C. G. (2011). Drivers of green supply management performance: Evidence from Germany. Journal of Purchasing and Supply Management, 17(3), 176-184.

Lecomber, R. (1975). Economic Growth versus the Environment. London: Macmillan. 
Miemczyk, J., Johnsen, T. E., \& Macquet, M. (2012). Sustainable purchasing and supply management: a structured literature review of definitions and measures at the dyad, chain and network levels. Supply Chain Management: An International Journal, 17(5), 478-496.

Mohrman, S. A., \& Worley, C. G. (2010). The organizational sustainability journey. Organizational Dynamics, 39(4), 289-294.

Neumayer, E. (2003). Weak versus strong sustainability: exploring the limits of two opposing paradigms (2nd ed.). Cheltenham: Edward Elgar Publishing.

Pagell, M., Chen-Lung, Y., Krumwiede, D. W., \& Sheu, C. (2004). Does the competitive environment influence the efficacy of investments in environmental management? Journal of Supply Chain Management, 40(3), 30-39.

Pagell, M., \& Shevchenko, A. (2014). Why research in sustainable supply chain management should have no future. Journal of Supply Chain Management, 50(1), 44-55.

Paulraj, A. (2011). Understanding the relationships between internal resources and capabilities, sustainable supply management and organizational sustainability. Journal of Supply Chain Management, 47(1), 19-37.

Poole, M. S., \& Van de Ven, A. H. (1989). Using paradox to build management and organization theories. Academy of Management Review, 14(4), 562-578.

Rao, P. (2002). Greening the supply chain: A new initiative in South East Asia. International Journal of Operations \& Production Management, 22(5/6), 632-632.

Reuter, C., Goebel, P., \& Foerstl, K. (2012). The impact of stakeholder orientation on sustainability and cost prevalence in supplier selection decisions. Journal of Purchasing and Supply Management, 18(4), 270-281.

Rockström, J., Steffen, W., Noone, K., Persson, A., Chapin III, F. S., Lambin, E., . . Foley, J. (2009). Planetary boundaries:exploring the safe operating space for humanity. Ecology and Society, 14(2), 32. [online] URL: http://www.ecologyandsociety.org/vol14/iss32/art32/.

Shrivastava, P. (1995). Ecocentric management for a risk society. Academy of Management Review, 20(1), 118-137.

Solow, R. M. (1974). Inter-generational equity and exhaustible resources. The Review of Economic Studies, 41, 29-46.

Speth, J. G. (2008). The Bridges at the Edge of the World: Capitalism, the Environment, and the Crossing from Crisis to Sustainability. New Haven: Yale University Press.

Spicer, A., Alvesson, M., \& Kärreman, D. A. N. (2009). Critical performativity: the unfinished business of critical management studies. Human Relations, 62(4), 537-560.

Starik, M., \& Rands, G. P. (1995). Weaving an integrated web: multilevel and multisystem perspectives of ecologically sustainable organizations. Academy of Management Review, 20(4), 908-935.

Sutton, R. I., \& Staw, B. M. (1995). What theory is not. Administrative Science Quarterly, 40(3), 371384.

Touboulic, A., Chicksand, D., \& Walker, H. (2014). Managing Imbalanced Supply Chain Relationships for Sustainability: A Power Perspective. Decision Sciences, 45(4), 577-619.

Ulubeyli, S. (2013). Drivers of environmental performance of cement plants. Industrial Management + Data Systems, 113(8), 1222-1244.

UNDP. (2013). Human Development Report 2013. New York: UN.

van der Heijden, A., Driessen, P. P. J., \& Cramer, J. M. (2010). Making sense of Corporate Social Responsibility: Exploring organizational processes and strategies. [Article]. Journal of Cleaner Production, 18(18), 1787-1796.

Van Maanen, J. (1995). Style as Theory. Organization Science, 6(1), 133-143.

Wang, Z., \& Sarkis, J. (2013). Investigating the relationship of sustainable supply chain management with corporate financial performance. International Journal of Productivity and Performance Management, 62(8), 871-888.

Weick, K. E. (1989). Theory construction as disciplined imagination. Academy of Management Review, 14(4), 516-531.

Weick, K. E. (1995). What theory is not, theorizing is. Administrative Science Quarterly, 40(3), 385390. 
Whiteman, G., Walker, B., \& Perego, P. (2013). Planetary Boundaries: Ecological Foundations for Corporate Sustainability. Journal of Management Studies, 50(2), 307-336.

Wickert, C., \& Schaefer, S. M. (2015). Towards a progressive understanding of performativity in critical management studies. Human Relations, 68(1), 107-130.

Wu, Z., Ellram, L. M., \& Schuchard, R. (2014). Understanding the Role of Government and Buyers in Supplier Energy Efficiency Initiatives. Journal of Supply Chain Management, 50(2), 84-105.

WWF. (2014). The living planet report: species and spaces, people and places. In W. International (Ed.). Gland, Switzerland.

Zhu, Q., \& Sarkis, J. (2004). Relationships between operational practices and performance among early adopters of green supply chain management practices in Chinese manufacturing enterprises. Journal of Operations Management, 22(3), 265-289.

Zhu, Q., \& Sarkis, J. (2007). The moderating effects of institutional pressures on emergent green supply chain practices and performance. [Article]. International Journal of Production Research, 45(18/19), 4333-4355.

Zhu, Q., Sarkis, J., \& Lai, K.-h. (2013). Institutional-based antecedents and performance outcomes of internal and external green supply chain management practices. Journal of Purchasing and Supply Management, 19(2), 106-117. 
FIGURE 1

Sociological Framework on Organizational Paradigms

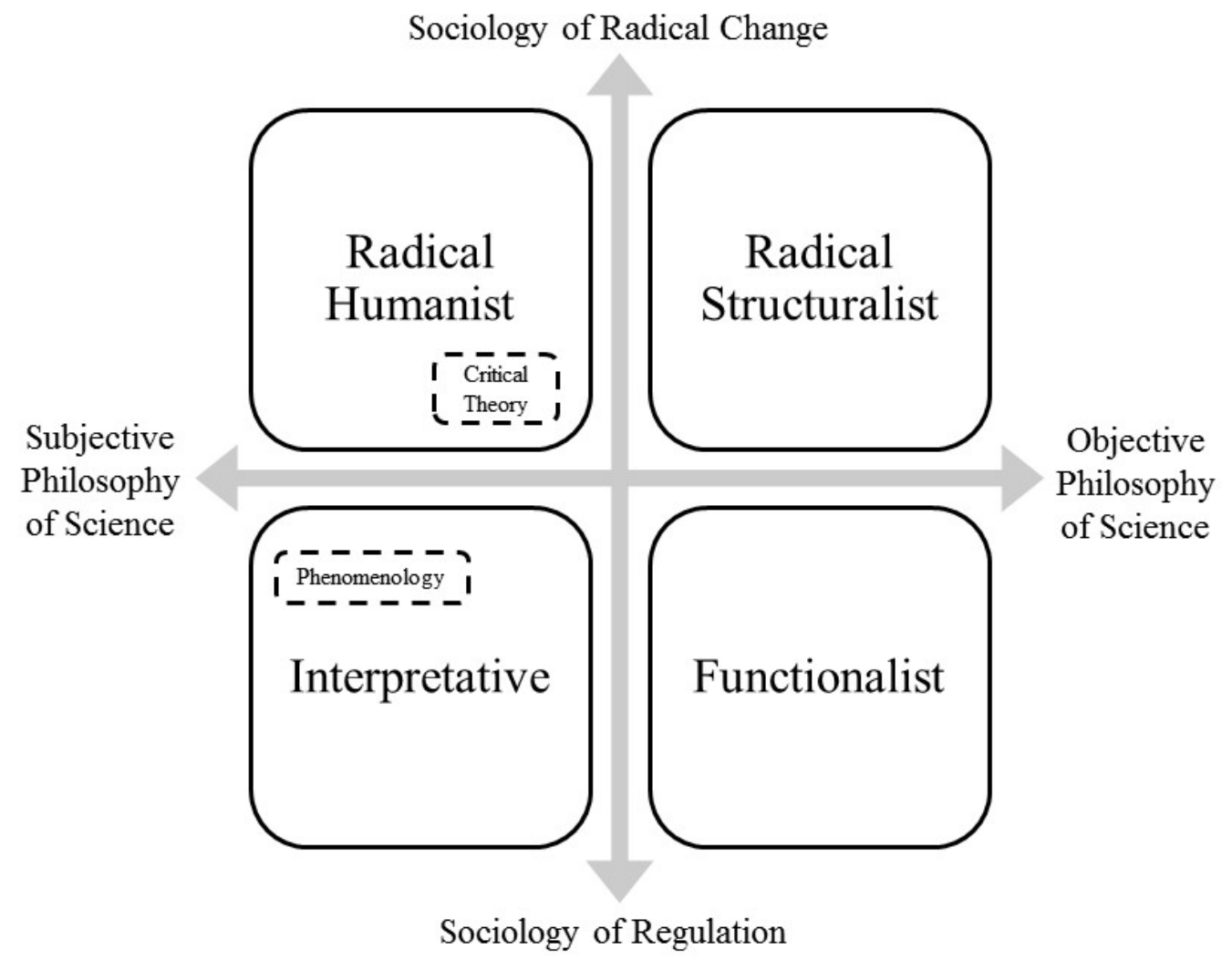

Source: Burrell and Morgan (1979) 
FIGURE 2

The Four Paradigms of Sustainability

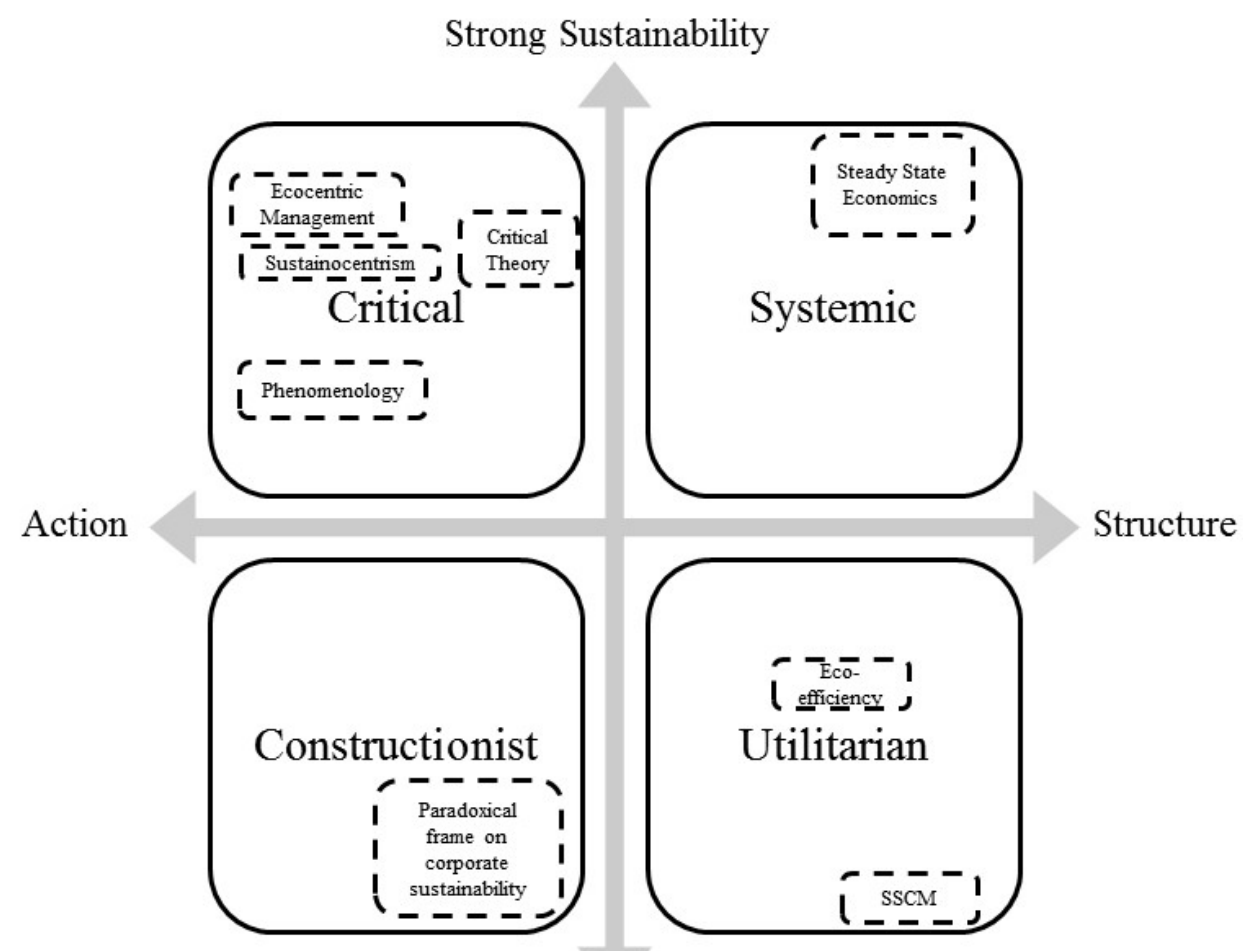

Weak Sustainability 
TABLE 1

\section{Environmental Performance in the extant SSCM Literature}

\begin{tabular}{|c|c|c|}
\hline \multirow[t]{2}{*}{ Planet Boundaries } & \multicolumn{2}{|c|}{ Existing SSCM Literature } \\
\hline & Measures & Measurement \\
\hline $\begin{array}{l}\text { Boundary 1: } \\
\text { Chemical pollution }\end{array}$ & $\begin{array}{l}\text { * Decrease of consumption for hazardous/harmful/toxic materials } \\
\text { * Decrease of frequency for environmental accidents } \\
\text { (Green Jr., Zelbst, Bhadauria, et al., 2012; Green Jr., Zelbst, } \\
\text { Meacham, et al., 2012; Laosirihongthong et al., 2013; Paulraj, } \\
\text { 2011; Ulubeyli, 2013; Zhu \& Sarkis, 2004, 2007; Zhu et al., 2013) } \\
\text { * Avoidance of materials that are considered harmful, but not } \\
\text { illegal (González et al., 2008) }\end{array}$ & $\begin{array}{l}\text { All studies have measured firm-level subjective } \\
\text { data (survey-based). } \\
\text { Example 1: "Please indicate the extent to which } \\
\text { you perceive that your plant has achieved each of } \\
\text { the following during the past year (five-point scale: } \\
1 \text { not at all; } 2 \text { a little bit; } 3 \text { to some degree; } 4 \\
\text { relatively significant; } 5 \text { significant)" (Green Jr., } \\
\text { Zelbst, Bhadauria, et al., 2012) }\end{array}$ \\
\hline $\begin{array}{l}\text { Boundary } 2: \\
\text { Climate change }\end{array}$ & $\begin{array}{l}\text { * Reduction of solid waste disposal } \\
\text { * Reduction of air emissions } \\
\text { (Chiou et al., 2011; Gimenez \& Sierra, 2013; Green Jr., Zelbst, } \\
\text { Bhadauria, et al., 2012; Green Jr., Zelbst, Meacham, et al., 2012; } \\
\text { Laosirihongthong et al., 2013; Large \& Thomsen, 2011; Pagell, } \\
\text { Mark et al., 2004; Paulraj, 2011; Rao, 2002; Ulubeyli, 2013; Zhu \& } \\
\text { Sarkis, 2004, 2007; Zhu et al., 2013) } \\
\text { * Increase of the level of recycling } \\
\text { (Gimenez \& Sierra, 2013; González et al., 2008; Large \& Thomsen, } \\
\text { 2011; Rao, 2002) } \\
\text { * Increase use of standardized components to facilitate their reuse } \\
\text { (González et al., 2008) } \\
\text { * Reduction of pollution (Gimenez \& Sierra, 2013; Large \& } \\
\text { Thomsen, 2011) } \\
\text { * Increase in energy saved due to conservation and efficiency } \\
\text { improvements (Laosirihongthong et al., 2013; Paulraj, 2011) }\end{array}$ & $\begin{array}{l}\text { All studies have measured firm-level subjective } \\
\text { data (survey-based). } \\
\text { Example 2: "Indicators measuring buyer } \\
\text { performance were operationalized to assess the } \\
\text { change in performance in the past 2-3 years. } \\
\text { Accordingly, these indicators were captured using } \\
\text { a 7-point Likert scale with end points of not at all } \\
\text { and significant" (Paulraj, 2011) }\end{array}$ \\
\hline
\end{tabular}




\begin{tabular}{|c|c|c|}
\hline $\begin{array}{l}\text { Boundary } 3: \\
\text { Fresh water use }\end{array}$ & $\begin{array}{l}\text { * Reduction of waste water } \\
\text { (Green Jr., Zelbst, Bhadauria, et al., 2012; Green Jr., Zelbst, } \\
\text { Meacham, et al., 2012; Pagell, Mark et al., 2004; Paulraj, 2011; } \\
\text { Rao, 2002; Ulubeyli, 2013; Zhu \& Sarkis, 2004, 2007; Zhu et al., } \\
\text { 2013) }\end{array}$ & $\begin{array}{l}\text { All studies have measured firm-level subjective } \\
\text { data (survey-based). } \\
\text { Example 3: "Respondents were asked to evaluate } \\
\text { the significance level of performance improvement } \\
\text { due to GSCM practices with a five point scale, } \\
\text { ranging from } 1=\text { one, to } 5=\text { very significant" } \\
\text { (Zhu et al., 2013) }\end{array}$ \\
\hline $\begin{array}{l}\text { Boundary 4: } \\
\text { Rate of biodiversity loss }\end{array}$ & $\begin{array}{l}\text { * Preserve the environment } \\
\text { (Gimenez \& Sierra, 2013; Hong et al., 2009; Large \& Thomsen, } \\
\text { 2011; Rao, 2002) }\end{array}$ & $\begin{array}{l}\text { All studies have measured firm-level subjective } \\
\text { data (survey-based). } \\
\text { Example 4: "In the last two years because of } \\
\text { implementing better management practices there } \\
\text { has been specific benefits achieved in each of the } \\
\text { following categories ( }(1=\text { no benefit ... } 4= \\
\text { substantial benefit)" (Rao, 2002) }\end{array}$ \\
\hline $\begin{array}{l}\text { Boundary 5: } \\
\text { Land use } \\
\text { Boundary } 6: \\
\text { Ozone depletion }\end{array}$ & \multirow{4}{*}{$\mathrm{N} / \mathrm{a}$} & \multirow{4}{*}{$\mathrm{N} / \mathrm{a}$} \\
\hline $\begin{array}{l}\text { Boundary } 7 \text { : } \\
\text { Global nitrogen \& phosphorus }\end{array}$ & & \\
\hline $\begin{array}{l}\text { Boundary 8: } \\
\text { Atmospheric aerosol loading }\end{array}$ & & \\
\hline $\begin{array}{l}\text { Boundary 9: } \\
\text { Ocean acidification }\end{array}$ & & \\
\hline
\end{tabular}

